\section{Vozes Dissonantes de Escravizados em Terras Alagoanas}

\section{Pontuações Iniciais}

Danilo Luiz Marques acertou ao escolher como ponto de partida para a pesquisa de sua tese de doutorado, Sob a "Sombra" de "Palmares": escravidão, memória e resistência na Alagoas oitocentista", a lacuna de pesquisas historiográficas sobre o protagonismo de escravos, libertos e livres no processo de desestabilização da instituição escravista em Alagoas. Temos, ainda, muito a percorrer nesse caminho dentro e fora da Academia. Trago dois exemplos recentes de textos publicados em 2016 e 2015.

De fora da Academia: a última obra de José Ramos Tinhorão, intitulada Rei do Congo ${ }^{2}$, deixa o leitor incomodado, pois uma noção perpassa quase todo o texto: a de que os africanos não estão na posição de sujeitos da própria história. Tudo é consequência da ação dos portugueses. De dentro da Academia: penso que um dos muitos méritos do magnífico livro de Angela Alonso, Flores, Votos e Balas ${ }^{3},-$ Marques abre um diálogo fecundo com ele na tese - é recolocar na agenda histográfica brasileira o debate sobre as "causas" que levaram à abolição. No entanto, um ruído permanece ao longo da leitura, ruído já presente no início da obra, quando a autora afirma que a abolição não "foi nem obra dos escravos, nem da princesa" (p. 17). Alonso não explicita, como deveria, a importância da participação dos escravizados no processo. O que reiteradamente a tese relembra e demonstra.

\section{Revisitando os Capítulos}

A tese está estruturada em três partes articuladas e coesas. Na primeira, Histórias, Memórias e Culturas Quilombolas, composta por três capítulos, quer responder a questão: Como ocorreu a diáspora africana em Alagoas? (p. 80) 4 . Ao respondê-la, recoloca Alagoas no coração do tráfico. "Alagoas foi um importante ponto de desembarque de africanos e, além de receptora de escravizados, também os

1 Tese defendida no Programa de Estudos Pós-Graduados em História da Pontifícia Universidade Católica de São Paulo, no dia 9 de março de 2018.

2 TINHORÃO, J. R. Rei Congo: a mentira histórica que virou folclore. São Paulo: Editora 34, 2016.

3 ALONSO. A. Flores, votos e balas: o movimento abolicionista brasileiro (1868-1888). São Paulo: Companhia das Letras, 2015.

4 No texto indicaremos apenas as páginas da tese.
Prof. Ênio José da Costa Brito

Professor Titular do

Programa de Estudos Pós-

Graduados em Ciência

da Religião da PUC-SP,

Coordenador do Grupo

de Pesquisa "Imaginário

Religioso Brasileiro (Veredas)"

e Vice coordenador do

Centro de Estudos Culturais

Africanos e da Diáspora

(CECAFRO-PUCSP). Editor da

Revista Último Andar. 
exportou na segunda metade do oitocentos" (p. 80). Constata o predomínio de uma forte presença bantu em Alagoas, presença de uma cultura angolana e de africanos muculmanos (p. 75), e ainda aponta para a presença dos quilombos como territórios de preservação/ recriação cultural (p. 82).

Destaco, a seguir, três tópicos marcantes, um de cada capítulo. "Nas culturas africanas, a vida era e continua sendo uma atividade intensamente performativa e ritualizada, se tornando aporte importante para vislumbrar memórias e histórias das populações afro diaspóricas" (p. 84). No capítulo segundo, apresenta o processo de transformação histórico-social das culturas africanas em Alagoas, ilustrando essas transformações com práticas sócio-políticas culturais, como o quilombo (p. 87), o negro fugido e o lambe-sujo (p. 109). Manifestações que simbolizam a resistência dos antigos escravizados (p. 109) e relembram as lutas e os anseios de liberdade (p. 98). A terceira passagem versa sobre a importância do corpo para manter vivos, por parte das populações afro-diaspóricas, os anseios e o seu horizonte de liberdade (p. 119).

Sediciosos, salteadores e amotinados: as resistências à escravidão dos Malês, Cabanos e Marimbondos (1810-1901) é o título da segunda parte. Para um comentário geral dos três capítulos que a compõem, tomo como mote uma afirmação de Marcus Carvalho, apresentada por Marques: "O historiador da resistência escrava deve ter em mente a conjuntura e as circunstâncias locais" (p. 165).

O conceito de resistência é central nesses capítulos, é central no olhar do pesquisador sobre os documentos e no diálogo com eles. Da leitura, pode-se inferir que resistir não significa apenas fugir, rebelar-se. Resistir ao sistema significa diversificar as estratégias de acordo com as peculiaridades de cada região e de cada período do escravismo. No fundo, os capítulos apontam para a importância de jamais destituir de suas historicidades o ocorrido, as intervenções e os personagens. Na leitura desses capítulos, sente-se que autor ampliou o conceito de resistência ao tomá-lo em suas historicidades.
Vale pontuar que a leitura desses três capítulos nos dá a conhecer uma sociedade complexa, móvel, cheia de contradições no seio da qual escravizados, libertos e livres pobres aparecem como protagonistas. Destaco uma categoria presente transversalmente no texto, a da mobilidade. Ela aponta para o dinamismo que marcava a sociedade e as relações sociais aí engendradas.

Enfatiza nos capítulos dessa segunda parte que a resistência e insubordinação escrava foram um fenômeno global, negado, silenciado, esvaziado do seu conteúdo político pelos escravocratas (p. 153). Relembrando a importância de se explicitar o projeto político de resistência escrava, que na documentação oficial foi relegado para um segundo plano.

Temos, ainda, uma sugestiva informação sobre a cabanada, que, iniciada por membros das elites provinciais (p. 173), se transformaria gradualmente em uma guerra insurrecional popular antiescravista, saindo do controle dos proprietários rurais (p. 184), na qual os escravizados se tornam o grupo mais influente, assumindo a ideia de luta contra a escravidão.

Terminando essa segunda parte, Marques traz um comentário de Maria Luiza Oliveira sobre o problema que a contagem dos escravizados poderia acarretar para os Africanos livres. João José Reis, com a acuidade que the é peculiar, relembra que: a expressão "Africano Livre" é um "eufemismo jurídico", expressão tipicamente ideológica, que esconde uma realidade bem diversa da enunciada. Vale lembrar que, no contexto da Lei Eusébio de Queiroz, de 1850, os abolicionistas brasileiros se mobilizaram com vigor em torno do que mandava a regra de 1831, quanto à liberdade dos escravos ilegalmente introduzidos no país 5 .

A terceira parte intitula-se Quilombolas, Malfeitores e mais alguns salteadores: os temerosos e incertos últimos anos da escravidão (1870-1880), também ela com três capítulos.

5 Para uma visão da complexa problemática relacionada com os africanos livres, ver MAMIGONIAN, Beatriz Galloti. Africanos livres: a abolição do tráfico de escravos no Brasil. São Paulo: Companhia das Letras, 2017. 
Parte reveladora de preocupações e desejos do pesquisador. Preocupações que, por meio da análise dos ofícios (p. 235) e de falas das autoridades, quer mostrar aos seus leitores: "quão tumultuosos foram os últimos anos da instituição escravista na província alagoana" (p. 242); quer refletir sobre conexões analíticas possiveis entre os movimentos abolicionistas e a atuação de escravizados, libertos e libertados, "como partes integrantes de um amplo movimento social e político, de uma superação da escravidão (p. 244-245). Desejo de levar os leitores a uma compreensão mais densa/refinada do processo de abolição e do protagonismo dos escravizados.

Alguns tópicos desenvolvidos na terceira parte chamam atenção e impressionam pela atualidade: o esforço do grupo hegemônico que, pressentindo o fim da escravidão, buscou estabelecer "vínculos legais calcados em relações de dependência em um novo estatuto legal" (p. 261).

Impressiona como a escravidão estruturou um modo de vida, definiu identidades, possibilidades e destinos das pessoas (da sociedade imperial) (p. 272) e como o grupo hegemônico utilizou a mão de obra escrava o quanto pôde e depois a responsabilizou pelo atraso do país (p. 273).

Finalizando, a terceira parte nos relembra que a elite escravista procurou fazer transbordar para a sociedade no pós-abolição as regras sociais que balizavam o mundo escravista (p. 333). No bojo dessa dinâmica, creio ser possível pensar que se quis também impor aos libertos uma concepção de liberdade que, com certeza, não era a desejada e pelo qual lutavam os escravizados. A liberdade para os escravizados era pertencer a uma comunidade, a uma linhagem, no interior da qual, a cada ciclo de vida, se submetiam a rituais significativos de iniciação e se verificava sua inserção no processo produtivo, como nos lembra João José Reis.

\section{Conclusão}

Sabemos que uma boa História Geral deita raízes numa sólida História Regional. Olhando a tese Sob a sombra de Palmares, pode-se consta- tar que não só dá uma contribuição significativa para a historiografia regional, como também para a geral.

Marques, mesmo sabendo das dificuldades que envolviam seu tema, conseguiu levantar uma consistente documentação nos arquivos, dialogou com uma vasta gama de pesquisadores(as). Evitou armadilhas que ocorrem com frequência em pesquisadores da Diáspora. Não considerou as heranças afrodescendentes como residuais, evitou concepções dicotômicas e não viu as práticas africanas como coletivas, mas como comunitárias. Não contentou em dizer que experiências de Áfricas se manifestam em Alagoas, mas buscou entendê-las em profundidade. Considerou os marcos, símbolos e signos da cultura negra no seu valor civilizatório.

Sob a sombra de Palmares é recomendada para todos que querem compreender um pouco mais o nosso passado para pensar e construir o futuro da nação brasileira. Nação que, nos dias atuais, assiste estarrecida ao desmonte de suas conquistas sociais e pode constatar diariamente que o DNA colonial e escravagista não admite qualquer ousadia dos subalternos na busca de seus direitos de liberdade e de igualdade. 
